\title{
Changes emerging with calcinerin inhibition in Caenorhabditis elegans individuals as an aging model
}

\section{Bir yaşlanma modeli olarak Caenorhabditis elegans bireylerinde kalsinörin inhibisyonu ile ortaya çıkan değişiklikler}

Mustafa Tosun¹, Sibel Berksoy Hayta ${ }^{2}$, Melih Akyol², Sedat Özçelik²

Dermatology Department, Sivas Numune Hospital, Sivas, Turkey

2 Cumhuriyet University School of Medicine, Dermatology Department, Sivas, Turkey

Corresponding author: Mustafa Tosun, Dermatology Department, Sivas Numune Hospital, Sivas, Turkey

E-mail: doktor699@hotmail.com

Received/Accepted: September 05, 2015 / September 06, 2017

Conflict of interest: There is not a conflict of interest.

\section{SUMMARY}

Objective: It is known that calcineurin inhibition prolongs life in individuals with Caenorhabditis elegans (C. elegans). An important part of $C$. elegans genes shows great similarity to human genes. This study aims to evaluate the effects of a calcineurin inhibitor on vital functions in C. elegans individuals.

Method: In this study, solutions of cyclosporine A which is a calcineurin inhibitör $1 \mu \mathrm{M}$ (1.dose), $0.1 \mu \mathrm{M}$ ( 2. dose), 0.01 $\mu \mathrm{M}$ (3.dose) and $0.001 \mu \mathrm{M}$ (4.dose) were prepared and $1 \mathrm{ml}$ from each solution was taken and added to petri dishes, containing $10 \mathrm{ml}$ Nematode Growth Media (NGM). The control group was fed the medium which was not added cyclosporine. The indicated doses of cyclosporine whose synchronization has been completed were transferred to petri dishes in order that each would have 20 pieces. C. elegans were observed using bottom light stereo microscop that provided 6X-50X magnification. Live animals at the same time every day were counted and compared with the control group until all C. elegans in all petri dishes died.

Results: The results have showed that there was a statistically significant increase in life span periods of $C$. elegans exposed to cyclosporin depending on dose increase $(\mathrm{p}<0,05)$. It has been found out that physical development of $C$. elegans exposed to increased doses of cyclosporin decreased significantly $(\mathrm{p}<0,05)$. The increase in doses of cyclosporin have not caused statitically significant change in the number of pharynx pumping $(\mathrm{p}>0,05)$.

Conclusions: Calcineurin inhibition slows down the developmental process in C. elegans and prolongs survival, and may produce positive effects on aging.

Keywords: Caenorhabditis elegans, calcineurin, cyclosporine A, skin aging

\section{ÖZET}

Amaç: Kalsinörin inhibisyonunun Caenorhabditis elegans (C. elegans) bireylerinde yaşam süresini uzattığ1 bilinmektedir. C. elegans genlerinin önemli bir kısmı insan genlerine büyük benzerlik göstermektedir. Bu çalışmada kalsinörin inhibisyonunun $C$. elegans bireylerindeki yaşamsal fonksiyonlar üzerine olan etkilerinin değerlendirilmesi amaçland1.

Yöntem: Çalışma için bir kalsinörin inhibitörü olan siklosporin A'nın $1 \mu \mathrm{M}$ (1.doz), $0.1 \mu \mathrm{M}$ (2.doz), $0.01 \mu \mathrm{M}$ (3.doz) ve $0.001 \mu \mathrm{M}$ (4.doz) dozunda çözeltileri hazırlanarak her bir çözeltiden 1'er ml, içlerinde 10' ar ml Nematod Growth Media (NGM) bulunduran petrilere eklenmiştir. Kontrol grubu siklosporin eklenmemiş besiyerinde beslenmiştir. Senkronizasyonu yapılmış C. elegans'lardan siklosporinin belirtilen dozları ile hazırlanmış her bir petriye 20' şer adet aktarılmıştır. 6X-50X arasında büyütme sağlayan alttan 1şıklandırmalı stereo mikroskop ile C. elegans'lar izlenmiştir. Bütün petrilerdeki C. elegans'lar ölene kadar her gün aynı saatte canlı hayvanlar sayılmış ve kontrol grubuyla karşılaştırılmıştır.

Bulgular: Çalışma sonucunda siklosporine maruz bırakılan C. elegans'ların kontrol grubuna göre yaşam sürelerinde doz artışına bağlı istatistiksel olarak anlamlı bir artış olduğu tespit edilmiştir $(\mathrm{p}<0,05)$. Siklosporine maruz bırakılan $C$. 
elegans'ların fiziksel gelişimlerinin doz artışına bağlı olarak anlamlı derecede azaldığı saptanmıştır $(\mathrm{p}<0,05)$. Siklosporin dozundaki artış farinks pompalama sayısında istatistiksel olarak anlamlı bir değişikliğe neden olmamıştır $(p>0,05)$.

Sonuç: Kalsinörin inhibisyonu, C. elegans'ların gelişimsel sürecini yavaşlatır ve yaşam süresini uzatır. Kalsinörin inhibitörleri, benzer mekanizmalarla insanlarda deri yaşlanması üzerine olumlu etki yapabilir. Bu nedenle kalsinörin inhibisyonunun, deri yaşlanması üzerine etkinliğini ve etki mekanizmasını açıklayacak ileri çalışmalar gereklidir.

Anahtar sözcükler: Caenorhabditis Elegans, Kalsinörin, Siklosporin A, Deri Yaşlanması

\section{INTRODUCTION}

Skin aging is a complex biological process that inevitably occurs over time. In the development of this process, genetic, metabolic and endocrine factors, and ultraviolet play a role ${ }^{1}$. Long-term ultraviolet exposure increases metalloproteinase activity, which causes the collagen damage. According to the free radical theory, in photoaging, free oxygen radicals form due to the photooxidative stress. These create oxidative effect on collagens and other metalloproteins. Moreover, fibroblast, keratinocytes, melanocytes, Langerhans cell functions deteriorate due to oxidation ${ }^{2}$.

Caenorhabditis elegans (C. elegans) is a microscopic, non-pathogenic nematode, which lives in tree roots in nature ${ }^{3}$. Although it is a nonmammal living creature, it is used as a model for neurodegenerative diseases and many other diseases such as aging, metabolic syndrome, cancer and depression ${ }^{4}$.

Calcineurin activity has been measured directly in cells that populate skin, including melanocytes and keratinocytes ${ }^{5}$. Moreover, inhibition of calcineurin has been shown to block proliferation and differentiation of cultured keratinocytes ${ }^{6,7}$. In the C. elegans nematode, calcineurin plays a major role in cellular processes related to development, reproduction, proliferation, behavior, movements, and lifespan ${ }^{8-10}$.

This present study was aimed at investigating the effects of calcineurin inhibition by cyclosporine on vital functions of $C$. elegans which can be used as an aging model.

\section{MATERIAL AND METHODS}

Research approval was obtained from Cumhuriyet University Animal Experiments Ethics Committee prior to the study.

Wild-type C. elegans (N2) and Escherichia coli OP5O strains used in the experiment were purchased from the Caenorhabditis Genetics Center (CGC) at the University of Minnesota.

During the experiment, $2.5 \mathrm{~g}$ Peptone, $3 \mathrm{~g} \mathrm{NaCl}$ and $20 \mathrm{~g}$ agar were dissolved in $1 \mathrm{~L}$ of distilled water. Then they were autoclaved at $125^{\circ} \mathrm{C}$ for 15 minutes and cooled down to $55^{\circ} \mathrm{C}$. Previously prepared 1ml MgSO4 (1M), $1 \mathrm{ml}$ Cholesterol (5 $\mathrm{mg} / \mathrm{ml}), 1 \mathrm{ml} \mathrm{CaCl} 2(1 \mathrm{M})$ and $25 \mathrm{ml} \mathrm{K} 2 \mathrm{HPO} 4$ buffer were filtered through $0.2 \mu \mathrm{m}$ porous filters, and were homogenized by adding to the $\mathrm{pH} 7$ medium. For the experiment, $1 \mu \mathrm{m}\left(1^{\text {st }}\right.$ dose $), 0.1$ $\mu \mathrm{m}$ ( $2^{\text {nd }}$ dose $), 0.01 \mu \mathrm{m}\left(3^{\text {rd }}\right.$ dose $)$ and $0.001 \mu \mathrm{m}\left(4^{\text {th }}\right.$ dose) cyclosporine solutions were prepared. From each solution, $1 \mathrm{ml}$ was added to petri dishes each of which included $10 \mathrm{ml}$ of Nematode Growth Media (NGM). After they were homogenized, NGMs were cooled and solidified. Previously prepared Escherichia coli OP50 strain was added to the solidified NGM and dried in a sterile cabinet. In the control group, cyclosporine was not added, samples were fed in the medium ${ }^{11}$.

NGMs to be used in the lifespan analysis were prepared as described above. However, during the lifespan analysis, in order to avoid development of C. elegans eggs, fluorodeoxyuridine (FUDR) was added to the NGM during the preparation stage. Of the synchronized C. elegans, 20 were transferred to each petri dish prepared with the aforementioned doses of cyclosporine. C. elegans were viewed with the stereomicroscope with a 6X-50X magnification range. Until C. elegans in all the petri dishes died, live animals were counted and compared with those in the control group.

While 20 adult $C$. elegans were transferred into petri dishes which contained NGMs including the same doses of cyclosporine but no fluorodeoxyuridine which were prepared to investigate the pharyngeal pumping rate of $C$. elegans per minute, in order to investigate the physical development, C. elegans at the first larval stage (L1) were transferred. To observe the physical development of $C$. elegans, the petri dishes were checked and compared with those in the control group. The experiments were repeated 3 times at $21^{\circ} \mathrm{C}$ with 5 petri dishes.

The results of the experimental and control groups were compared with the t-test. P values $<0.05$ were considered statistically significant. Statistical analysis of the data was performed using the SPSS (Statistical Package for Social Sciences-14). This work was supported by the Research Fund of Cumhuriyet University (T-604). 


\section{RESULTS AND DISCUSSION}

The lifespan analysis of C. elegans exposed to cyclosporine is given in Table 1.

Table 1. Lifespan rates of $C$. elegans exposed to cyclosporine

\begin{tabular}{|lcl|}
\hline Groups & Mean \pm Standard Deviation & p \\
\hline Control $-1^{\text {st }}$ dose & $-11.20 \pm 11.87$ & $0.000^{*}$ \\
\hline Control $-2^{\text {nd }}$ dose & $-8.96 \pm 12.81$ & $0.002^{*}$ \\
\hline Control $-3^{\text {rd }}$ dose & $-6.64 \pm 11.69$ & $0.009^{*}$ \\
\hline Control $-4^{\text {th }}$ dose & $-2.36 \pm 8.58$ & 0.182 \\
\hline $1^{\text {st }}$ dose $-2^{\text {nd }}$ dose & $2.24 \pm 5.65$ & 0.059 \\
\hline $1^{\text {st }}$ dose $-3^{\text {rd }}$ dose & $4.56 \pm 7.09$ & $0.004^{*}$ \\
\hline $1^{\text {st }}$ dose $-4^{\text {th }}$ dose & $8.84 \pm 8.04$ & $0.000^{*}$ \\
\hline $2^{\text {nd }}$ dose $-3^{\text {rd }}$ dose & $2.32 \pm 3.70$ & $0.005^{*}$ \\
\hline $2^{\text {nd }}$ dose $-4^{\text {th }}$ dose & $6.60 \pm 7.14$ & $0.000^{*}$ \\
\hline $3^{\text {rd }}$ dose $-4^{\text {th }}$ dose & $4.28 \pm 5.18$ & $0.000^{*}$ \\
\hline
\end{tabular}

* Mean values are significant for $\mathbf{p}<0.05$ ( $\mathrm{t}$ test)

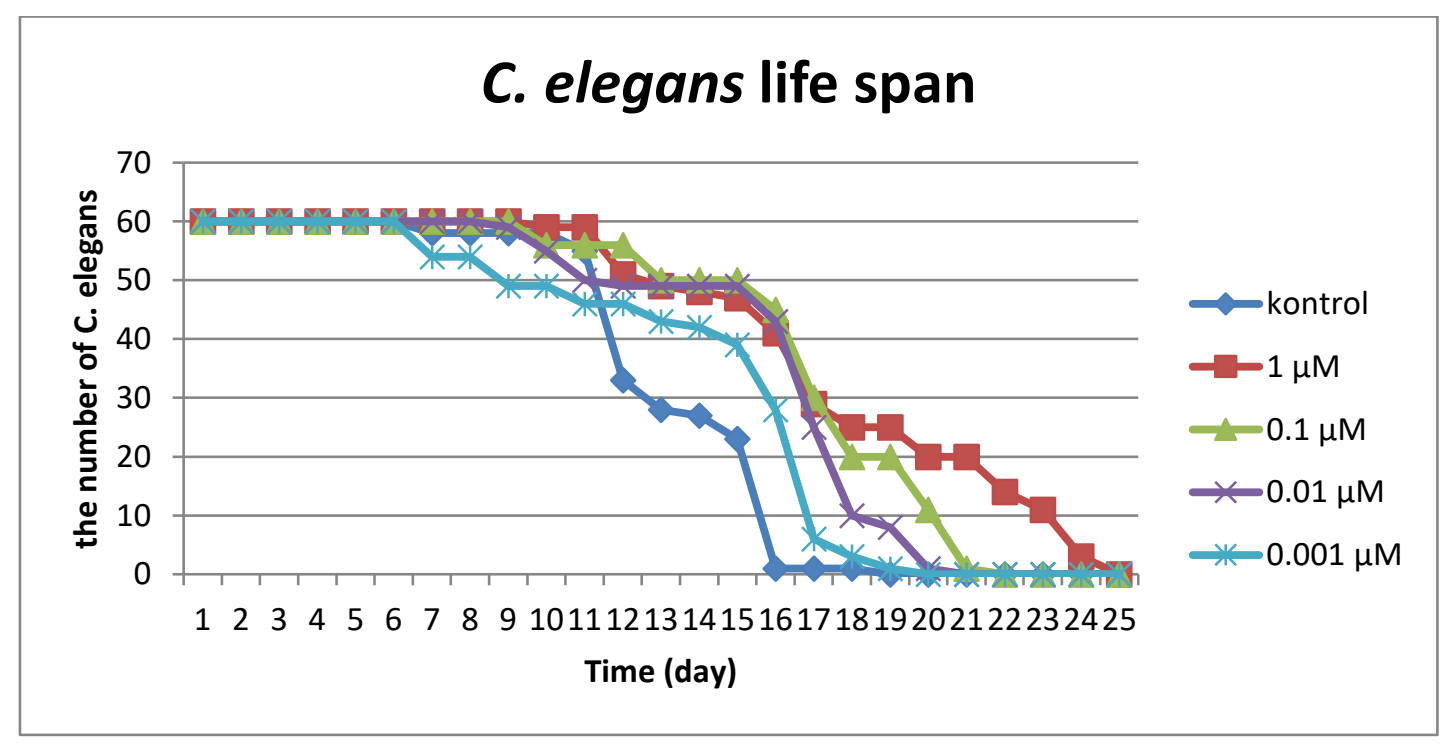

Figure 1. Lifespan in C. elegans exposed to cyclosporine (control and $1^{\text {st }}, 2^{\text {nd }}, 3^{\text {rd }}, 4^{\text {th }}$ doses)

According to Table 1 and Figure 1, an increase was observed in the lifespans of C. elegans exposed to cyclosporine in parallel with dose increases. 
Table 2. Physical development in C. elegans exposed to cyclosporine

\begin{tabular}{|lll|}
\hline Groups & Mean \pm Standard Deviation & p \\
\hline Control $-1^{\text {st }}$ dose & $1.53 \pm 0.28$ & $0.000^{*}$ \\
\hline Control $-2^{\text {nd }}$ dose & $0.65 \pm 0.47$ & $0.000^{*}$ \\
\hline Control $-3^{\text {rd }}$ dose & $0.11 \pm 0.47$ & 0.309 \\
\hline Control $-4^{\text {th }}$ dose & $-0.09 \pm 0.49$ & 0.396 \\
\hline $1^{\text {st }}$ dose $-2^{\text {nd }}$ dose & $-0.87 \pm 0.33$ & $0.000^{*}$ \\
\hline $1^{\text {st }}$ dose $-3^{\text {rd }}$ dose & $-1.41 \pm 0.47$ & $0.000^{*}$ \\
\hline $1^{\text {st }}$ dose $-4^{\text {th }}$ dose & $-1.62 \pm 0.31$ & $0.000^{*}$ \\
\hline $2^{\text {nd }}$ dose $-3^{\text {rd }}$ dose & $-0.54 \pm 0.57$ & 0.001 \\
\hline $2^{\text {nd }}$ dose $-4^{\text {th }}$ dose & $-0.75 \pm 0.47$ & $0.000^{*}$ \\
\hline $3^{\text {rd }}$ dose $-4^{\text {th }}$ dose & $-0.21 \pm 0.68$ & 0.192 \\
\hline
\end{tabular}

* Mean values are significant for $p<0.05$ (t test)

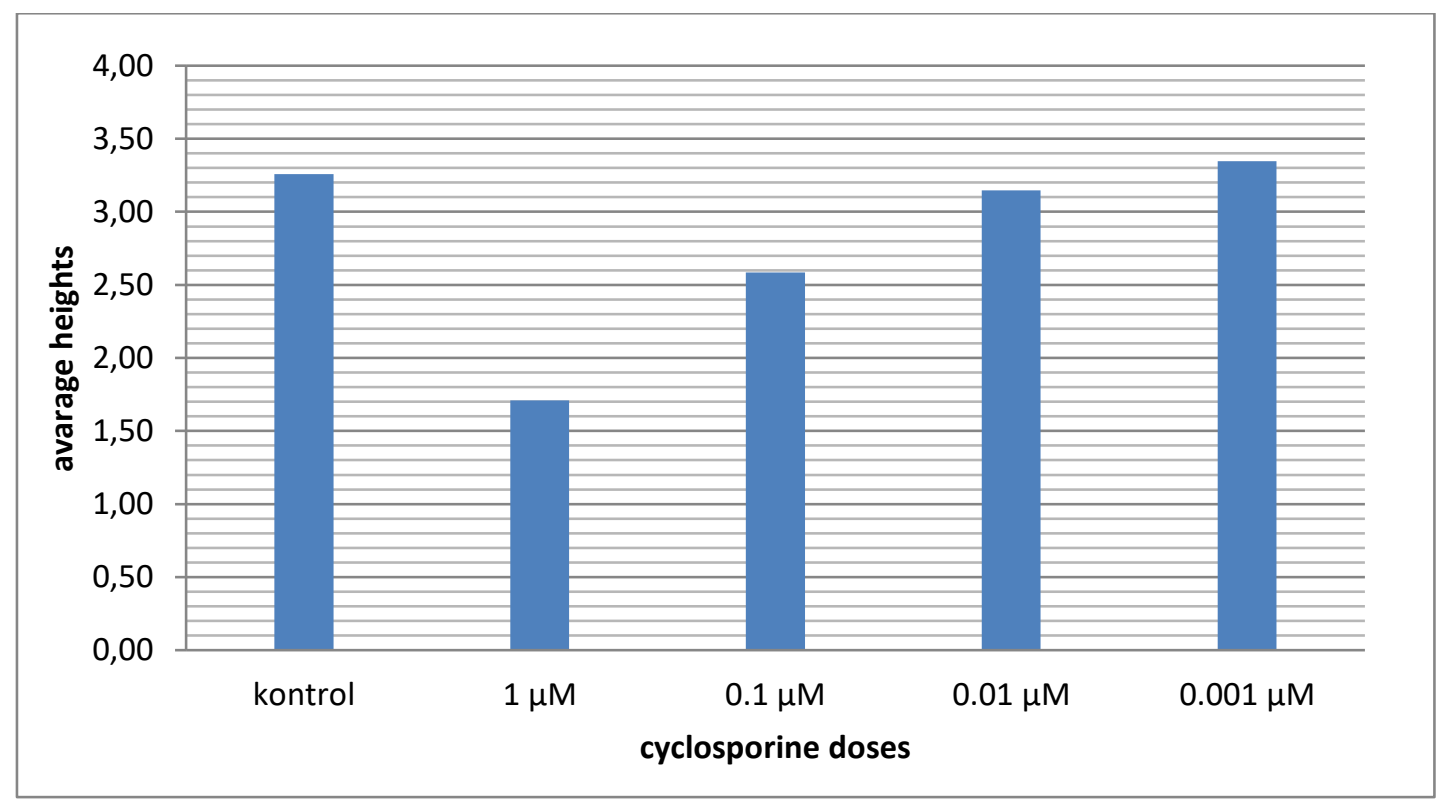

Figure 2. The physical development of C. elegans exposed to cyclosporine

According to Table 2 and Figure 2, an increase was observed in the physical development of C. elegans exposed to cyclosporine in parallel with decreases in doses.

In the controls conducted at the end of the $3^{\text {rd }}$ day, it was observed that the physical development of $C$. elegans at the first larval stage (L1) decreased as the dose of the cyclosporine increased.

According to the Picture 1, the images of $C$. elegans at the first larval stage (L1) exposed to cyclosporine obtained from the stereo microscope on the third day showed that their physical development slowed down as the dose increased. 


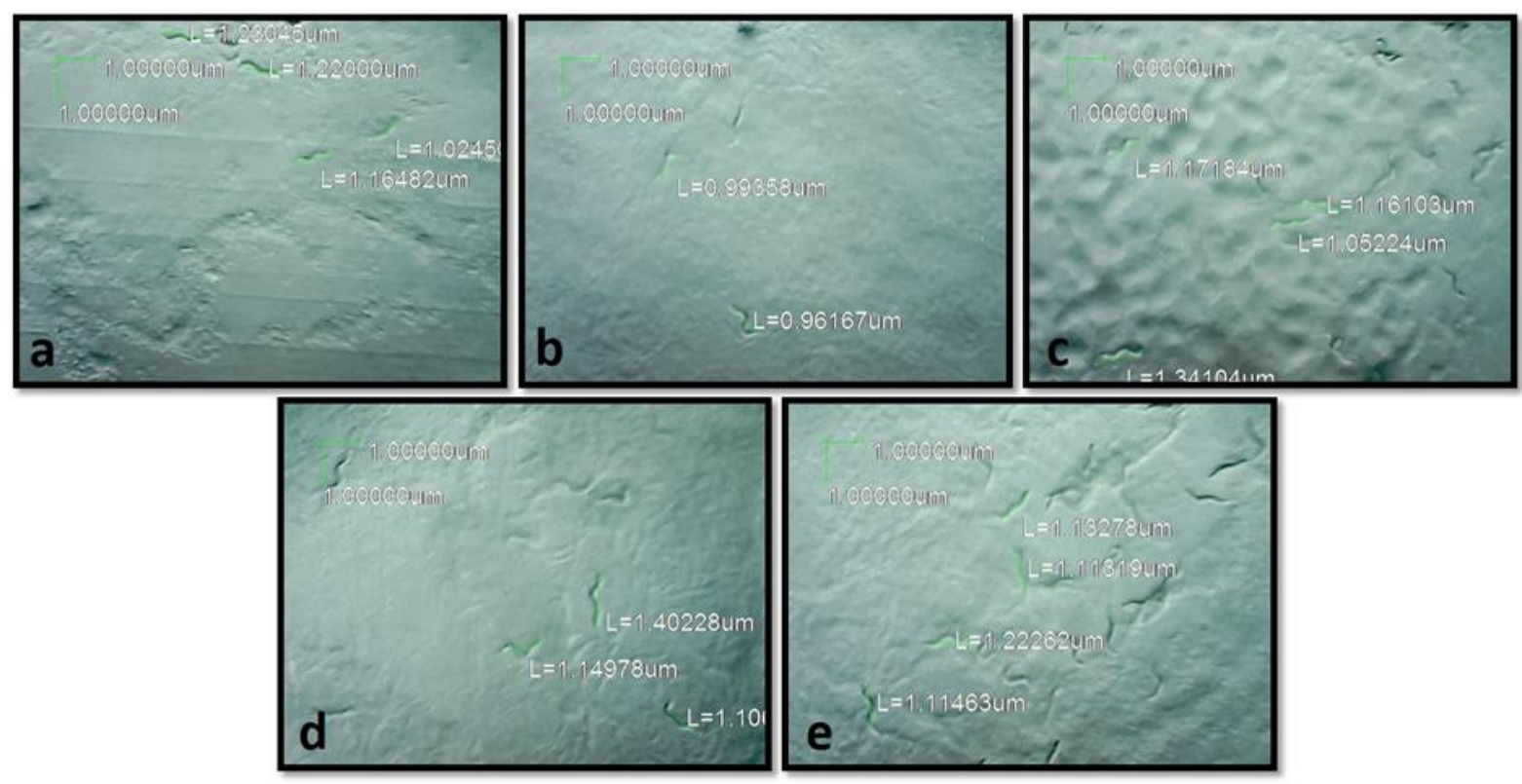

Picture 1. Physical developments of C. elegans after three days: a) Control (x3), b) $1 \mu \mathrm{M}$ cyclosporine (x3), c) $0.1 \mu \mathrm{M}$ cyclosporine (x3), d) $0.01 \mu \mathrm{M}$ cyclosporine (x3), e) $0.01 \mu \mathrm{M}$ cyclosporine (x3)

The comparison of the groups in terms of the pharyngeal pumping rates demonstrated that the difference was not significant ( $p>0.05$ ).

Aging is a multisystem complex and progressive process resulting from the accumulation of cellular damage left unrepaired ${ }^{12}$. C. elegans, a soil nematode, can be used as a model in studies investigating molecular mechanisms underlying the aging process ${ }^{13}$. The advantage of $C$. elegans is that it allows the observation and analysis of the effects of a drug on the entire organism, which makes it an appropriate model to be used in agingrelated studies. Determination of the genome sequence will facilitate the modeling of many diseases and investigating of the effects of various chemicals ${ }^{14}$.

Several factors such as neuroendocrine signals, nutritional factors and mitochondrial functions determine the lifespan of $C$. elegans. C. elegans becomes an adult in 3 days through 4 larval stages (L1, L2, L3 and L4). The lifespan of an adult $C$. elegans is $18-20$ days (at $20^{\circ} \mathrm{C}$ ). Under adverse environmental conditions such as nutrient deficiency and heat, C. elegans become dauer larvae and can live up to 60 days ${ }^{15,16}$.

In mammalians, calcineurin, a $\mathrm{Ca}^{2+} /$ calmodulindependent serine / threonine phosphatase, is involved in $\mathrm{T}$ cell activation and the development of the heart ${ }^{17}$. Calcineurin is produced in tissues such as the nervous system, muscle, hypodermis and vulva. In many developmental and cellular processes of organisms, T-cell activation is involved in skeletal and cardiac muscle development, memory and apoptosis ${ }^{18}$. Cardiac hypertrophy has been determined to be associated with many diseases such as Alzheimer's disease, schizophrenia, diabetes and muscular dystrophy ${ }^{19}$.

In the $C$. elegans nematode, calcineurin is effective on the body volume, muscle contraction and lifespan. In the $C$. elegans nematode, calcineurin plays a major role in cellular processes related to development, reproduction, proliferation, behavior, movements and lifespan ${ }^{8-10}$.

Calcineurin has been shown to increase the levels of matrix metalloproteinases (MMP) in the cardiac atrial myocytes by means of the nuclear factor of activated T-cells (NFAT) 20. Matrix metalloproteinases (MMPs) secreted from epidermal keratinocytes and dermal keratinocytes are responsible for collagen destruction. MMPs are matrix-degrading enzymes that play an important role in various destructive processes such as inflammation, tumor invasion and skin aging ${ }^{21,22}$. A variety of stimuli such as cytokine release, UV and oxidative stress increase MMP levels. Skin aging occurs extrinsically and intrinsically (in chronological order). Changes in collagen, the basic element of the skin, occur both in intrinsic and in extrinsic aging ${ }^{23,} 24$. Expression of the transient receptor potential vanilloid 1 (TRPV1) increases due to UV exposure, and in turn the extrinsic and intrinsic aging increase ${ }^{21}$.

Levels of MMP-1 and, though to a lesser extent, levels of other two collagenases (MMP-8 and MMP-13) were higher in the skin exposed to UV than were those in the normal skin. MMP-1 plays a 
major role in photoaging ${ }^{25} . \mathrm{Ca}^{2+}$ regulates the activation of MMPs. $\mathrm{Ca}^{2+}$ influx that occurs through protein kinase $\mathrm{C}$ (PKC) dependent TRPV1 in keratinocytes plays a key role in UV-induced MMP-1 expression. The UV-stimulated intracellular $\mathrm{Ca}^{2+}$ increase is the cofactor source for PKC and is important in the activation of $\mathrm{Ca}^{2+} /$ calmodulin pathway. $\mathrm{Ca}^{2+}$ is involved in intracellular signaling, and the growth, migration and differentiation of the cells ${ }^{26}$.

$\mathrm{Ca}^{2+}$ plays a role in many phenomena such as a second messenger and gene expression. $\mathrm{Ca}^{2+}$ mediates intracellular signaling by activating the dependent protein kinase and phosphatase. In eukaryotic cells, of the $\mathrm{Ca}^{2+}$ dependent pathways, the best known is calcineurin, a serine / threonine specific protein phosphatase. Calcineurin is inhibited by cyclosporine $\mathrm{A}^{27,28}$.

In the present study, cyclosporine which antagonizes the intracellular effects of $\mathrm{Ca}^{2+}$ and inhibits calcineurin led to a significant increase in the lifespans of $C$. elegans individuals in parallel with dose increases. Compared to the control group, a significant increase was determined in the lifespan of members of the groups treated with cyclosporine.

Investigations of the effects of cyclosporine on the vital functions of $\mathrm{C}$. elegans individuals revealed that the physical development of $C$. elegans left exposed to cyclosporine significantly reduced in parallel with the changes in doses. Moreover in the present study, the increase in the cyclosporine dose did not cause a significant change in the pharyngeal pumping rate.

In their study investigating the effects of strontium chloride hexahydrate on the lifespan, physical development and pharyngeal pumping rate in $C$. elegans individuals, Akyol et al. determined that depending on the doses of strontium, while the lifespan increased, physical development decreased, which is parallel to the results of the present study. They also reported that the pharyngeal pumping rate decreases due to the increase in $\operatorname{dose}^{29}$. However, in the present study, no changes were observed in the pharyngeal pumping rate. This is because while strontium reduces the $\mathrm{Ca}^{2+}$ entry into the cell, cyclosporine does not have such an effect. On the other hand, in Dallas et al.'s study, calcineurin increased the pharyngeal pumping rate in the $C$. elegans individuals while a high dose of cyclosporine A (40 $\mu \mathrm{M})$ decreased the pharyngeal pumping rate ${ }^{30}$. In the present study, that no significant change was observed in the pharyngeal pumping rate is probably due the low dose of cyclosporine.
In conclusion, the inhibition of calcineurin slows down the developmental process of $C$. elegans and extends their lifespan. It is possible to create a positive impact on aging through the inhibition of calcineurin.

\section{REFERENCES}

1. Ünlü E. Deri yaşlanmasında korunma ve tedavi yöntemleri. Dermatoz 2010; 1: 23-31.

2. Ünal İ, Ertam İ. Factors Contributing to Skin Aging. Turkiye Klinikleri J Cosm Dermatol Special Topics 2008; 1: 1-7.

3. Hertweck M, Hoppe T, Baumeister R. C. elegans, a model for aging with highthroughput capacity. Exp Gerontol 2003; 38: 345-6.

4. Olsen A, Vantipalli MC, Lithgow GJ. Using Caenorhabditis elegans as a model for aging and age-related diseases. Ann N Y Acad Sci 2006; 1067: 120-8.

5. Smit NP, Van Rossum HH, Romijn FP, Sellar KJ, Breetveld M, Gibbs S et al. Calcineurin activity and inhibition in skin and (epi) dermal cell cultures. J Invest Dermatol 2008; 128:1686-90.

6. Fisher GJ, Duell EA, Nickoloff BJ, Annesley TM, Kowalke JK, Ellis CN et al. Levels of cyclosporin in epidermis of treated psoriasis patients differentially inhibit growth of keratinocytes cultured in serum free versus serum containing media. J Invest Dermatol 1988; 91: 1426.

7. Nickoloff BJ, Fisher GJ, Mitra RS, Voorhees JJ. Direct cytopathic effects of cyclosporine A on rapidly proliferating cultured keratinocytes and dermal fibroblasts. Transplant Proc 1988; 20: 8590.

8. Bandyopadhyay J, Lee J, Lee JI, Yu JR, Jee C, Cho JH, et al. Calcineurin, a calcium/calmodulindependent protein phosphatase, is involved in movement, fertility, egg laying, and growth in Caenorhabditis elegans. Mol Biol Cell 2002; 13: 3281-93.

9. Kuhara A, Inada H, Katsura I, Mori I. Negative regulation and gain control of sensory neurons by the C. elegans calcineurin TAX-6. Neuron 2002; 33: 751-63.

10. Lee J, Jee C, Song HO, Bandyopadhyay J, Lee $\mathrm{JI}, \mathrm{Yu}$ JR, et al. Opposing functions of calcineurin and CaMKII regulate g-protein signaling in egglaying behavior of C. elegans. J Mol Biol 2004; 344: 585-95. 
11. Sutphin GL, Kaeberlein M. Measuring Caenorhabditis elegans lifespan on solid media. J Vis $\operatorname{Exp} 2009$; 12: 1152.

12. Hekimi S and Guarente L. Genetics and the specificity of the aging process. Science 2003; 299:1351-54.

13. Luo Y. Long-lived worms and aging. Redox Rep 2004; 9: 65-9.

14. Corsi AK. A Biochemist guide to C. elegans. Anal Biochem 2006; 359: 1-17.

15. Guarente L, Kenyon C. Genetic pathways that regulate aging in model organisms. Nature 2000; 408: $255-62$.

16. Klass MR. A method for the isolation of longevity mutants in the nematode caenorhabditis elegans and initial results. Mech Age Dev 1983; 22: $279-86$.

17. Crabtree GR. Generic signals and specific minireview outcomes: signaling through $\mathrm{Ca} 2+$, calcineurin, and NF-at. Cell 1999; 96: 611-4.

18. Kingsbury TJ and Cunningham KW. A conserved family of calcineurin regulators. Genes Dev 2000; 14: 1595-604.

19. Lee JI, Mukherjee S, Yoon KH, Dwivedi M, Bandyopadhyay J. The multiple faces of calcineurin signaling in Caenorhabditis elegans: development, behaviour and aging. J Biosci 2013; 38:417-31.

20. Sayg1lı E, Rana O. R, Meyer C, et all. The angiotensin-calcineurin-NFAT pathway mediates stretch-induced up-regulation of matrix metalloproteinases-2/-9 in atrial myocytes. Basic Res Cardiol 2009; 104: 435-48.

21. Lee YM, Kim YK, Chung JH. Increased expression of TRPV1 channel in intrinsically aged and photoaged human skin in vivo. Exp Dermatol 2008; 18: 431-6.

22. Vincenti MP, Brinckerhoff CE. Transcriptional regulation of collagenase (MMP-1, MMP-13) genes in arthritis: integration of complex signaling pathways for the recruitment of gene specific transcription factors. Arthritis research 2002; 4: 157-64.

23. Fisher GJ, Wang ZQ, Datta SC, Varani J, Kang S, Voorhees JJ. Pathophysiology of premature skin aging induced by ultraviolet light. N Engl J Med 1997; 337: 1419-28.

24. Varani J, Warner RL, Gharaee-Kermani M et al. Vitamin A antagonizes decreased cell growth and elevated collagen-degrading matrix metalloproteinases and stimulates collagen accumulation in naturally aged human skin. J Invest Dermatol 2000; 114: 480-6.

25. Varani J, Hattori Y, Chi Y, Schmidt T, Perone $\mathrm{P}$, Zeigler ME, et al. Elaboration of collagenolytic and gelatinolytic matrix metalloproteinases and their inhibitors by basal cell carcinomas of skin: comparison with normal skin. Br J Cancer 2000; 82: $657-65$.

26. Hwang YP, Kim HG, Han EH, et al. NAcetylglucosamine suppress collagenases activation in ultraviolet B-irradiated human dermal fibroblasts: Involvement of calcium ions and mitogen-activated protein kinases. J Dermatol Sci 2011; 63: 93-103.

27. Clapham DE. Calcium signaling. Cell 1995; 80: 259-68.

28. Hunter T. Protein kinases and phosphatases: the yin and yang of protein phosphorylation and signaling. Cell 1995; 80: 225-36.

29. Akyol M, Özpınar N, Hayta SB, Özçelik S. Deri yaşlanması için bir model olarak Caenorhabditis elegans bireylerinde stronsiyum klorid heksahidrat'n etkileri. XXV. Ulusal Dermatoloji Kongresi, 21-25 Ekim 2014, Antalya.

30. Donohoe DR, Jarvis RA, Weeks K, Aamodt EJ and Dwyer DS. Behavioral adaptation in C. elegans produced by antipsychotic drugs requires serotonin and is associated with calcium signaling and calcineurin inhibition. Neurosci Res 2009; 64: 280-89. 